\title{
PENGARUH PENGGUNAAN MEDIA PEMBELAJARAN TERHADAP MOTIVASI BELAJAR SISWA PADA MATA PELAJARAN AKUNTANSI
}

\author{
Ajang Mulyadi, M. Arief Ramdhany, Defrina Sari Tilawati
}

\begin{abstract}
ABSTRAK
Penelitian ini berawal dari sebuah fenomena yang terjadi di SMA Negeri 18 Bandung, dimana motivasi belajar siswa pada mata pelajaran Akuntansi bisa dikatakan rendah. Hal ini ditunjukkan oleh sebuah data awal berupa data absensi siswa kelas XI IPS pada mata pelajaran Akuntansi. Terdapat banyak hal yang dapat mempengaruhi motivasi belajar siswa. Dalam penelitian ini, peneliti berfokus pada salah satu faktor yang mempengaruhi motivasi belajar, yaitu penggunaan media pembelajaran. Penelitian ini bertujuan untuk mengetahui gambaran mengenai penggunaan media pembelajaran dan motivasi belajar siswa kelas XII IPS di SMA Negeri 18 Bandung. Selain itu, penelitian ini juga bertujuan untuk mengetahui bagaimana pengaruh penggunaan media pembelajaran terhadap motivasi belajar siswa kelas XII IPS di SMA Negeri 18 Bandung. Metode yang digunakan pada penelitian ini adalah metode survey verifikatif. Populasi dalam penelitian ini adalah siswa kelas XII IPS sebanyak 140 siswa. Sampel yang diambil sebanyak 104 siswa. Teknik pengambilan sampel yang digunakan adalah teknik simple random sampling. Data mengenai penggunaan media pembelajaran dan motivasi belajar siswa didapatkan dengan menyebarkan angket. Pengujian statistik yang digunakan dalam penelitian ini, yaitu uji normalitas data, uji linieritas, analisis korelasi, uji determinasi dan uji signifikansi. Perhitungan statistik tersebut dibantu dengan software SPSS v.16 for Windows. Gambaran penggunaan media pembelajaran berdasarkan persepsi siswa berada pada kategori cukup, yaitu sebesar $65,38 \%$. Sedangkan motivasi belajar siswa menurut persepsi siswa berada pada kategori cukup pula dengan nilai sebesar $58,65 \%$. Hasil penelitian menunjukkan bahwa penggunaan media pembelajaran berpengaruh positif terhadap motivasi belajar siswa pada mata pelajaran Akuntansi. Hasil penelitian ini telah diuji dan diterima kebenarannya dengan tingkat kepercayaan 95\%. Hal ini dibuktikan dengan nilai korelasi sebesar 0,453 dan koefisien determinasi sebesar 0,205. Hal ini berarti bahwa penggunaan media pembelajaran mempengaruhi motivasi belajar siswa pada mata pelajaran Akuntansi sebesar 20,5\%. Sedangkan sisanya sebesar $79,5 \%$ dipengaruhi oleh faktor lainnya.
\end{abstract}

Kata Kunci : Penggunaan Media Pembelajaran, Motivasi Belajar Siswa

\section{Pendahuluan}

Prestasi belajar yang baik dan tinggi dapat dicapai melalui keseriusan dari berbagai pihak yang terlibat dalam dunia pendidikan, tidak terkecuali siswa itu sendiri. Tinggi rendahnya prestasi yang diperoleh siswa dapat dipengaruhi oleh banyak faktor, salah satunya adalah motivasi belajar siswa. Tidak semua siswa memiliki motivasi yang tinggi dalam belajar, termasuk dalam mempelajari Akuntansi. Terkadang kita menemukan siswa yang motivasi belajarnya rendah. Seperti fenomena yang ditemukan penulis pada siswa kelas XI IPS di SMA Negeri 18 Bandung, khususnya pada mata pelajaran Akuntansi.

Berdasarkan data presensi siswa kelas XI IPS di SMA Negeri 18 Bandung pada mata pelajaran Akuntansi yang 
kemudian diolah menjadi data absensi (ketidak-hadiran), baik dengan alasan sakit (S), ijin (I), alfa / tidak hadir tanpa keterangan (A) maupun dispensasi (D). Data tersebut digunakan sebagai acuan awal penelitian ini, terutama yang paling disoroti adalah banyaknya jumlah alfa. Hal tersebut menjadi masalah karena pada dasarnya siswa tidak diperbolehkan tidak hadir tanpa keterangan.

Perlu diketahui bahwa banyaknya jumlah alfa disini tidak hanya disebabkan oleh siswa tidak datang ke sekolah, tetapi juga dikarenakan banyak siswa yang datang ke sekolah namun tidak mengikuti mata pelajaran Akuntansi. Ketika mata pelajaran Akuntansi berlangsung, siswasiswa tersebut melakukan kegiatan lain seperti bermain sepak bola, jajan di kantin, mengobrol di luar kelas atau kegiatan lainnya yang tidak diijinkan atau dilakukan tidak pada waktunya. Walaupun guru atau pihak sekolah telah mengingatkan dan menegur siswa-siswa tersebut, namun siswa-siswa itu enggan untuk mengikuti proses pembelajaran Akuntansi. Oleh karena itu, siswa yang walaupun masuk ke sekolah tetapi tidak hadir saat kegiatan belajar mengajar (KBM) berlangsung dianggap alfa.

Data absensi ini dapat digunakan untuk mengetahui tingkat motivasi belajar siswa karena sesuai dengan salah satu indikator dalam mengidentifikasi tingkat motivasi belajar siswa yang dikemukakan oleh Makmun (2005 : 40), yaitu frekuensi kegiatan dalam periode tertentu. Hal ini berarti, banyaknya frekuensi siswa mempelajari Akuntansi dalam suatu periode dimana periode tersebut adalah KBM mata pelajaran Akuntansi.

Data absensi ini sesuai dengan indikator tersebut dikarenakan banyak siswa yang menunjukkan keengganan dalam mengikuti proses pembelajaran Akuntansi meskipun telah diperingati oleh pihak sekolah. Oleh karena itu, motivasi belajar siswa dapat dikatakan rendah.
Tentu saja ketidak-hadiran siswa di saat KBM berlangsung ini dapat memberikan efek negatif bagi siswa, yaitu materi pelajaran yang diterima siswa yang tidak hadir lebih sedikit dibandingkan siswa yang hadir saat KBM berlangsung. Dengan kata lain, siswa yang tidak hadir mengalami ketinggalan materi pelajaran.

Adapun rangkuman data yang penulis peroleh adalah sebagai berikut :

Tabel 1

\section{Data Absensi Siswa Kelas XI IPS SMA Negeri 18 Bandung}

Pada Mata Pelajaran Akuntansi

\begin{tabular}{|c|c|c|c|c|c|c|c|c|c|}
\hline \multirow{2}{*}{$\begin{array}{l}\text { Jml } \\
\text { Sis } \\
\text { wa }\end{array}$} & \multirow{2}{*}{$\begin{array}{c}\text { Jml } \\
\text { Tatap } \\
\text { Muka }\end{array}$} & \multicolumn{4}{|c|}{ Keterangan } & \multicolumn{4}{|c|}{ Persentase (\%) } \\
\hline & & S & I & A & $\mathrm{D}$ & $\mathrm{S}$ & I & $A$ & $\mathrm{D}$ \\
\hline 46 & 20 & 23 & 10 & 131 & 13 & 2,5 & 1,1 & 14,2 & 1,4 \\
\hline 48 & 19 & 26 & 8 & 95 & 1 & 2,9 & 0,9 & 10,4 & 0,1 \\
\hline 46 & 21 & 26 & 13 & 210 & 23 & 2,2 & 1,3 & 21,7 & 2,4 \\
\hline
\end{tabular}

Sumber : (Berdasarkan data presensi siswa kelas XI IPS SMA Negeri 18 Bandung, data diolah)

Keterangan :

$S=$ sakit

$\mathrm{I}=\mathrm{ijin}$

$A=$ alfa

$\mathrm{D}=$ dispensasi

Dari permasalahan diatas, perlu dilakukan analisis lebih lanjut mengenai penyebab rendahnya motivasi belajar siswa yang ditunjukkan melalui keengganan siswa mengikuti KBM pada mata pelajaran Akuntansi. Salah satu faktor penyebab yang mungkin terjadi adalah siswa menganggap kegiatan pembelajaran Akuntansi kurang menarik. Sehingga mereka kurang mendapatkan motivasi untuk hadir di kelas saat KBM berlangsung.

\section{Landasan Teori}

UNtuk meningkatkan motivasu belajar siswa, perlu dilakukan tindakan agar siswa dapat selalu hadir dalam mata pelajaran Akuntansi. Salah satunya adalah dengan membuat kegiatan belajar yang menarik sehingga dapat mempengaruhi 
motivasi siswa untuk hadir dan mengikuti proses pembelajaran Akuntansi di kelas. Hal ini seperti yang dikemukakan oleh Uno (2010 : 23) bahwa pada hakikatnya motivasi dapat timbul karena factor intrinsic berupa hasrat dan dorongan kebutuhan belajar, harapan dan cita-cita, selain itu dari factor ekstrinsik motivasi belajar siswa dapat dipengaruhi oleh penghargaan, lingkungan belajar yang kondusif dan kegiatan belajar yang menarik.

Salah satu upaya yang dapat dilakukan untuk meningkatkan motivasi belajar siswa adalah dengan cara membuat kegiatan belajar yang menarik. Untuk membuat kegiatan belajar yang menarik, kita dapat menggunakan media pembelajaran. Hal ini telah dikemukakan oleh beberapa ahli, diantaranya adalah Hamalik (Arsyad, 2011 : 15)

Pemakaian media pembelajaran dalam proses belajar mengajar dapat membangkitkan keinginan dan minat yang baru, membangkitkan motivasi dan rangsangan kegiatan belajar, dan bahkan membawa pengaruhpengaruh psikologis terhadap siswa.

Selain itu, Sudjana dan Rivai (2005 : 2) juga mengemukakan bahwa "salah satu manfaat media pengajaran dalam proses belajar siswa adalah pengajaran akan lebih menarik perhatian siswa sehingga dapat menumbuhkan motivasi belajar".

Secara umum, media memiliki berbagai kegunaan seperti yang diungkapkan oleh Sadiman (2008: 17), yaitu :

1. Memperjelas penyajian pesan agar tidak terlalu bersifat verbalistis (dalam bentuk katakata tertulis atau lisan saja)

2. Mengatasi keterbatasan ruang, waktu dan daya indera.

3. Menggunakan media pembelajaran secara tepat dan bervariasi dapat mengatasi sifat pasif anak.
4. Dengan sifat unik pada tiap siswa di tambah lagi dengan lingkungan dan pengalaman yang berbeda, sedangkan kurikulum dan materi pembelajaran ditentukan sama pada tiap siswa, maka guru banyak mengalami kesulitan bila semua itu harus diatasi sendiri. Hal ini akan lebih sulit bila latar belakang guru dengan siswa juga berbeda.

Dengan berbagai kegunaan di atas, media diharapkan mampu membantu guru dan siswa dalam proses belajar mengajar. Media pembelajaran membantu guru dalam menyampaikan materi pembelajaran. Media pembelajaran juga membantu siswa agar lebih mudah memahami pelajaran dan lebih termotivasi untuk belajar.

Media dapat dikelompokkan menjadi tujuh macam, yaitu benda untuk didemonstrasikan, komunikasi lisan, media cetak, gambar diam, gambar gerak, film bersuara dan mesin belajar. Ketujuh kelompok media tersebut dikaitkan dengan kemampuan memenuhi fungsi menurut tingkatan hierarki belajar yang dikembangkannya, yaitu pelontar stimulus belajar, penarik minat belajar, contoh perilaku belajar, memberi kondisi eksternal, menuntun cara berpikir, memasukkan alihilmu, memberi motivasi dan pemberi umpan balik.

Karakteristik atau ciri khusus yang dimiliki media pembelajaran berbeda-beda tergantung dari maksud dan tujuan pengelompokkannya. Jadi, klasifikasi media, karakteristik media dan pemilihan media merupakan sebuah kesatuan yang tak terpisahkan dalam penentuan strategi belajar.

Dengan menggunakan berbagai media pembelajaran yang sesuai dengan materi pembelajaran, kegiatan belajar akan berubah menjadi lebih menarik dibandingkan tanpa menggunakan media pembelajaran. Kegiatan belajar dapat semakin menarik jika pengajar mampu 
menggunakan media pembelajaran tersebut secara efektif. Media pembelajaran tersebut tidak akan efektif jika pengajar tidak dapat menggunakanya dengan baik. Oleh karena itu, pengajar harus mengikuti langkah-langkah dalam menggunakan media pembelajaran.

Sebelum menggunakan media pembelajaran, pengajar harus melakukan berbagai persiapan seperti mempelajari bagaimana petunjuk penggunaan media pembelajaran tersebut. Jangan sampai ketika di kelas, pengajar tidak mampu mengoperasikan media pembelajaran tersebut dengan baik. Dalam pelaksanaannya, pengajar juga harus memperhatikan kondisi kelas. Setelah itu, evaluasi diperlukan untuk mengetahui apakah penggunaan media pembelajaran tersebut mampu membuat proses pembelajaran menjadi lebih baik atau tidak. Hasil evaluasi diproses untuk kemudian ditindaklanjuti oleh pengajar.

\section{Metode Penelitian}

Dalam penelitian ini, metode yang digunakan adalah penelitian survei verifikatif. Dengan menggunakan metode penelitian survey verifikatif ini, diharapkan dapat memberikan gambaran yang akurat dan jelas mengenai pengaruh dari variabelvariabel yang diteliti.

Penelitian ini akan dilakukan di terhadap siswa kelas XII SMA Negeri 18 Bandung, sehingga populasi dalam penelitian ini adalah siswa kelas XII SMA Negeri 18 Bandung. Adapun data jumlah siswa tersebut adalah sebagai berikut :

Tabel 2 Data Populasi

\begin{tabular}{|c|c|c|}
\hline No & Kelas & $\begin{array}{c}\text { Jumlah } \\
\text { Siswa }\end{array}$ \\
\hline 1 & XII IPS 1 & 46 siswa \\
\hline 2 & XII IPS 2 & 48 siswa \\
\hline 3 & XII IPS 3 & 46 siswa \\
\hline \multicolumn{2}{|c|}{ Jumlah } & $\begin{array}{c}140 \\
\text { siswa }\end{array}$ \\
\hline
\end{tabular}

Sumber : ( SMA Negeri 18 Bandung bagian tata usaha)

Teknik pengambilan sampel yang digunakan adalah dengan menggunakan Simple Random Sampling. "Simple Random Sampling merupakan pengambilan anggota sampel dari populasi dilakukan secara acak tanpa memperhatikan strata yang ada dalam populasi itu" (Sugiyono, 2009 : 120). Penelitian ini menggunakan Simple Random Sampling dikarenakan seluruh anggota populasi diberikan peluang yang sama untuk menjadi sampel (probability sampling). Dengan menggunakan Simple Random Sampling ini, sampel yang diambil adalah sejumlah siswa yang terdaftar di SMA Negeri 18 Bandung.

Teknik pengumpulan data merupakan faktor yang penting dalam keberhasilan penelitian. Hal ini berkaitan dengan bagaimana cara mengumpulkan data, siapa sumbernya, dan apa alat yang digunakan. Metode pengumpulan data merupakan teknik atau cara yang dilakukan untuk mengumpulkan data. Metode menunjuk pada suatu cara sehingga dapat diperlihatkan penggunaannya melalui angket, wawancara,pengamatan, tes, dokumentasi dan sebagainya. Pengumpulan data akan dilakukan dengan menyebarkan angket kepada siswa. Untuk pengujian instrument digunakan uji reliabilitas dan uji validitas butir angket.

Teknik analisa data dan pengujian hipotesi menggunakan Korelasi Pearson Product Moment dengan melakukan uji normalitas dan uji linieritas terlebih dahulu.

\section{Hasil dan Pembahasan}

Motivasi belajar dapat dipengaruhi oleh dua faktor, yaitu faktor intrinsik dan faktor ekstrinsik. Yang termasuk faktor ekstrinsik diantaranya adalah kegiatan belajar yang menarik. Seperti yang ditulis oleh Uno (2010 : 23) dalam bukunya dimana, 
Hakikat motivasi dapat timbul karena faktor intrinsik berupa hasrat dan keinginan berhasil dan dorongan kebutuhan belajar, harapan akan cita-cita. Sedangkan faktor ekstrinsiknya adalah penghargaan, lingkungan belajar yang kondusif dan kegiatan belajar yang menarik.

Kegiatan belajar yang menarik dapat diciptakan oleh pengajar. Salah satu caranya adalah dengan menggunakan media pembelajaran yang atraktif sehingga pada akhirnya dapat mempengaruhi motivasi belajar siswa. Dalam subbab pembahasan hasil penelitian ini, dimuat penjelasan dan interpretasi hasil penelitian, implikasi dari hasil penelitian, deskripsi variabel penggunaan media pembelajaran dan motivasi belajar siswa.

Penelitian ini telah dilakukan oleh peneliti pada siswa kelas XII IPS di SMA Negeri 18 Bandung disertai dengan kajian teoritis yang tercantum dalam Bab II. Penelitian telah dilakukan terhadap siswa kelas XII IPS di SMA Negeri 18 Bandung yang populasinya sebesar 140 siswa dan sebanyak 104 siswa dijadikan sampel dengan menyebarkan angket.

Berdasarkan pengolahan data yang telah dilakukan, dapat disimpulkan bahwa hipotesis penelitian dimana penggunaan media pembelajaran berpengaruh positif terhadap motivasi belajar siswa bisa diterima. Hasil penelitian ini menguatkan penelitian sebelumnya yang telah dilakukan oleh Muniyawati $(2011: 115)$ dimana hasil penelitian tersebut adalah "persepsi penggunaan media pembelajaran memiliki pengaruh yang positif terhadap motivasi".

$\mathrm{Hal}$ ini juga sesuai dengan pendapat dari Sudjana dan Rivai (2005:2), yaitu "salah satu manfaat media pengajaran dalam proses belajar siswa adalah pengajaran akan lebih menarik perhatian siswa sehingga dapat menumbuhkan motivasi belajar." Selain itu, Hamalik (dalam Arsyad, 2011 : 15) juga mengatakan bahwa,
Pemakaian penggunaan media pembelajaran dalam proses belajar mengajar dapat membangkitkan keinginan dan minat yang baru, membangkitkan motivasi dan rangsangan kegiatan belajar, dan bahkan membawa pengaruhpengaruh psikologis terhadap siswa.

Dengan demikian, melalui penelitian ini kita dapat menduga bahwa semakin efektif media pembelajaran yang digunakan dalam mata pelajaran Akuntansi, maka motivasi belajar siswa dalam mempelajari Akuntansi semakin tinggi. Oleh karena itu, jika motivasi belajar diharapkan meningkat maka media pembelajaran harus digunakan secara lebih efektif. Adapun penggunaan media pembelajaran dapat dikatakan efektif jika memenuhi indikator penilaian yang telah dikemukakan oleh Sudjana dan Rivai (2005 : 4), yaitu :

1. Ketepatannya dalam tujuan pengajaran

2. Dukungan terhadap isi bahan pelajaran

3. Kemudahan memperoleh media

4. Keterampilan guru dalam menggunakannya

5. Tersedia waktu untuk menggunakannya

6. Sesuai dengan taraf berpikir siswa

$\begin{array}{ccr}\text { Berdasarkan analisis } & \text { deskripsi } \\ \text { variabel, diketahui } & \text { bahwa secara }\end{array}$ keseluruhan variabel penggunaan media pembelajaran di SMA Negeri 18 Bandung telah dipersepsi baik oleh siswa dan berada pada kategori cukup. Kategori cukup disini berarti bahwa media pembelajaran pada mata pelajaran Akuntansi di SMA Negeri 18 Bandung telah digunakan dengan cukup efektif. Hal ini dapat dilihat dari deskripsi setiap indikatornya dimana indikator ketepatan media pembelajaran dengan tujuan pembelajaran, dukungan media pembelajaran terhadap isi bahan pelajaran, kemudahan memperoleh media pembelajaran, ketersediaan waktu untuk menggunakan media pembelajaran dan 
tingkat kesesuaian media pembelajaran dengan taraf berpikir siswa berada pada kategori cukup. Sedangkan indikator keterampilan guru dalam menggunakan media pembelajaran berada pada kategori tinggi.

SMA Adapun motivasi belajar siswa di keseluruhan juga telah dipersepsi baik oleh siswa dan berada pada kategori cukup. Kategori cukup disini berarti bahwa siswa kelas XII IPS di SMA Negeri 18 Bandung memiliki motivasi belajar yang cukup tinggi. Hal ini dapat dilihat dari deskripsi setiap indikatornya dimana tiga indikator berada pada kategori tinggi, yaitu indikator persistensi (ketetapan dan kelekatan), tingkat aspirasi yang hendak dicapai dan tingkat kualifikasi prestasi atau produk atau output yang dicapai dari belajar. Sedangkan indikator lainnya, yaitu durasi kegiatan, frekuensi kegiatan, devosi (pengabdian) dan pengorbanan untuk mencapai tujuan, kesabaran, keuletan dan kemampuan dalam menghadapi rintangan dan kesulitan dalam mencapai tujuan belajar serta tingkat aspirasi yang hendak dicapai berada pada kategori cukup.

\section{Kesimpulan dan Saran}

\section{Kesimpulan}

Berdasarkan penelitian yang telah dilakukan, dapat ditarik kesimpulan sebagai berikut :

1. Hasil penelitian menunjukkan bahwa persepsi siswa mengenai penggunaan media pembelajaran pada mata pelajaran Akuntansi di kelas XII IPS SMA Negeri 18 Bandung berada pada kategori cukup.

2. Hasil penelitian menunjukkan bahwa persepsi siswa mengenai motivasi belajar siswa pada mata pelajaran Akuntansi di kelas XII IPS SMA Negeri 18 Bandung berada pada kategori cukup.

3. Hasil penelitian menunjukkan bahwa penggunaan media pembelajaran berpengaruh positif terhadap motivasi belajar siswa kelas XII IPS di SMA Negeri 18 Bandung.

\section{Saran}

Berdasarkan hasil penelitian, penulis dapat memberikan beberapa saran, yaitu :

1. Bagi Sekolah

a. Pihak sekolah juga diharapkan dapat meningkatkan fasilitas media pembelajaran di sekolah. Hal ini untuk mendukung dan membantu pengajar dalam penggunaan media pembelajaran. Sehingga tingkat kemudahan memperoleh media pembelajaran akan semakin tinggi.

b. Pihak sekolah memfasilitasi para pengajar untuk mengikuti kegiatan seperti seminar atau workshop guna memperluas wawasannya.

2. Bagi Pengajar

a. Sebaiknya keterampilan guru dalam menggunakan media pembelajaran dapat dipertahankan.

b. Pengajar sebaiknya menambah pengetahuan baik mengenai penggunaan media pembajaran maupun mengenai materi pelajaran itu sendiri.

c. Pengajar membuka pikiran dan wawasan mengenai perkembangan ilmu pengetahuan dan teknologi.

\section{Daftar Pustaka}

Arsyad. A. (2011). Media Pembelajaran. Jakarta : RajaGrafindo Persada

Ghazali, I. (2007). Aplikasi Analisis Multivariate Dengan Program SPSS. Semarang : Badan Penerbit UPI

Hasan, I. (2009). Analisis Data Penelitian Dengan Statistik. Jakarta : Bumi Aksara

Makmun, A.S. (2005). Psikologi Kependidikan : Perangkat Sistem Pengajaran Modul. Bandung : PT. Remaja Rosdakarya 
Narbuko, C. dan Achmadi, A. (2007). Metodologi Penelitian. Jakarta : Bumi Aksara

O'Bannon, B. W. dan Pucket, K. (2006). Preparing To Use Technology. USA : Pearson Education, Inc.

Purwanto, M. N. (2006). Psikologi Pendidikan. Bandung : Rosdakarya

Riduwan. (2010). Metodologi dan Teknik Menyusun Tesis. Bandung : Alfabeta

Sadiman, A.S. dkk. (2008). Media Pendidikan : Pengertian, Pengembangan dan Pemanfaatannya. Jakarta : RajaGrafindo Persada

Sekaran, U. (2011). Metodologi Penelitian Untuk Bisnis. Jakarta : Salemba Empat

Sudjana. (2003). Teknik Analisis Regresi dan Korelasi. Bandung : Tarsito

Sudjana, N. dan Rivai, A. (2005). Media Pengajaran. Bandung : Sinar Baru Algesindo

Sugiyono. (2009). Metode Penelitian Pendidikan. Bandung : Alfabeta

Sukmadinata, N.S. (2003). Landasan Psikologi Proses Pendidikan. Bandung : Remaja Rosdakarya

Suryabrata, S. (2008). Psikologi Pendidikan. Jakarta : RajaGrafindo Persada

Syah. M. (2011). Psikologi Pendidikan Dengan Pendekatan Baru. Bandung : Remaja Rosdakarya

Uno, H. B. (2010). Teori Motivasi dan Pengukurannya : Analisis di Bidang Pendidikan. Jakarta : Bumi Aksara

Odera, F. Y. (2011). "Motivation : The Most Ignored Factors In Classroom Instruction In Kenyan Secondary
School'. International Journal of Science and Technology. Vol 1 No. 6 p. 283

Rodgers, D. L. and Withrow-Thorton, B. J. (2005). "The Effect of Instructional Media On Learner Motivation". International Journal of Instructional Media. Vol 32 No. 4 p. 333-42 